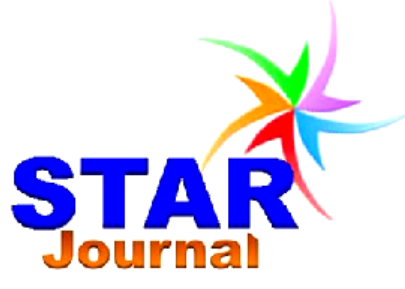

ISSN: 2226-7522(Print) and 2305-3327 (Online) Science, Technology and Arts Research Journal

July-Sep 2013, 2(3): 16-24

www.starjournal.org

Copyright@2013 STAR Journal. All Rights Reserved

Original Research

\title{
Determination of Water Requirement and Crop Coefficient for Sorghum (Sorghum bicolor L.) at Melkassa, Ethiopia
}

\author{
Abebe Shenkut $^{1}$, Kindie Tesfaye ${ }^{2^{\star}}$ and Fentaw Abegaz ${ }^{3}$ \\ ${ }^{1}$ Debre Tabour University, Debre Tabor, Ethiopia \\ ${ }^{2}$ International Livestock Research Institute, Addis Ababa, Ethiopia \\ ${ }^{3}$ Holetta Agricultural Research Ceneter, Holetta, Ethiopia
}

\begin{tabular}{|c|c|}
\hline Abstract & Article Information \\
\hline 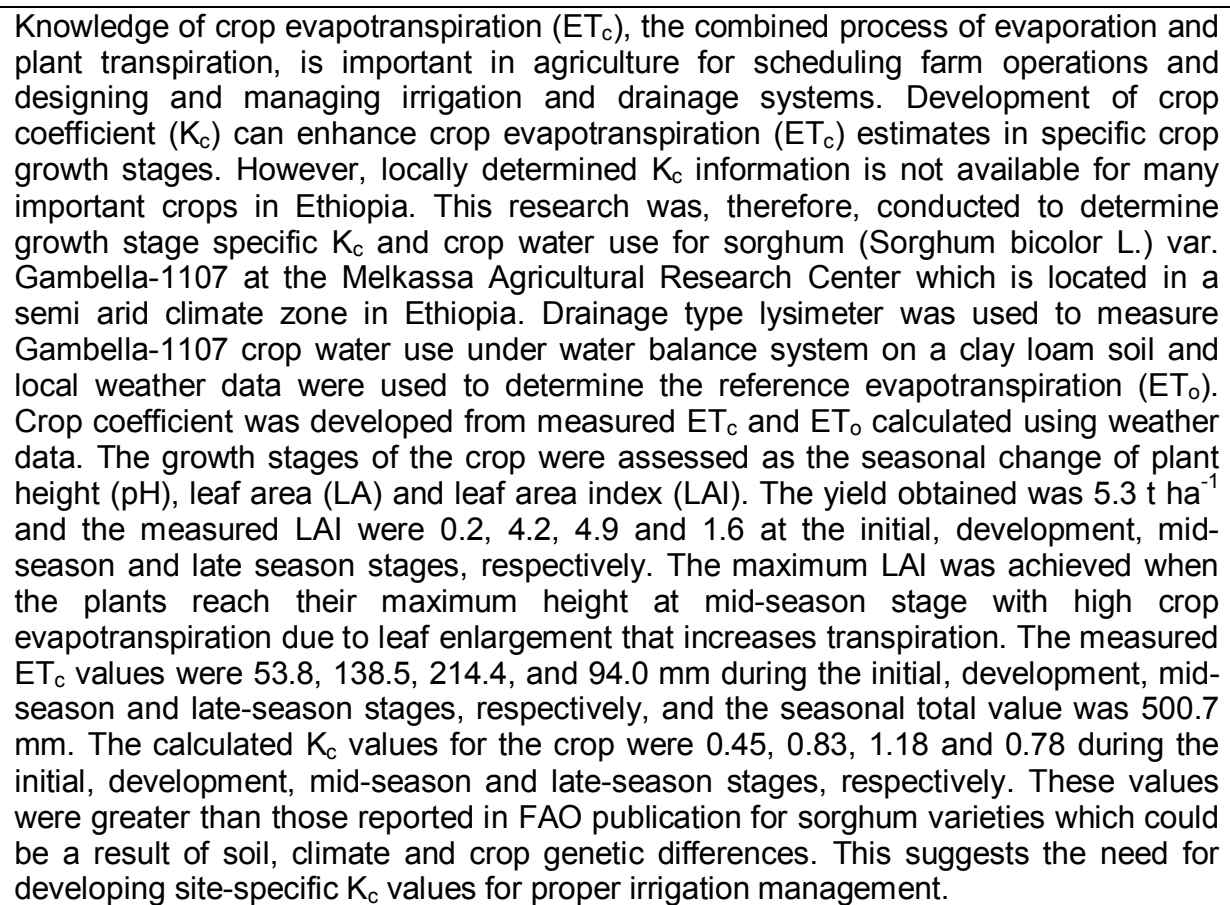 & $\begin{array}{l}\text { Article History: } \\
\text { Received : 05-07-2013 } \\
\text { Revised : 18-09-2013 } \\
\text { Accepted : 26-09-2013 } \\
\text { Keywords: } \\
\text { Crop Coefficient } \\
\text { Drainage lysimeter } \\
\text { Ethiopia } \\
\text { Evapotranspiration } \\
\text { Sorghum } \\
\text { `Corresponding Author: } \\
\text { Kindie Tesfaye } \\
\text { E-mail: } \\
\text { HANKID27@yahoo.com } \\
\text { Fentaw Abegaz } \\
\text { E-mail: } \\
\text { fentaw@rediffmail.com }\end{array}$ \\
\hline
\end{tabular}

\section{INTRODUCTION}

Water is one of the natural renewable resources essential for economic and social development. Yet, water resources have been taken for granted as a free good to be used at will, with little or no regard to the long-term consequences of its mismanagement. However, many voices have raised a note of alarm for some time now. For example, conferences have been held on environmental concerns including water, and UNESCO is focusing on the looming crisis of Fresh Water (Abu-Zeid and Hamdy, 2002).
The hydrological cycle describes the constant movement of water above, on and below the Earth's surface. The cycle operates across all scales, from the global to the smallest stream catchment (Smith, 1998) and involves the movement of water along evapotranspiration, precipitation, surface runoff, subsurface flow, and groundwater pathways. Evapotranspiration (ET) is usually the largest component of the hydrologic cycle, given that most precipitation that falls on land is returned to the 
Abebe Shenkut et al.,

atmosphere. Globally, about $60 \%$ of annual precipitation falling over the land surface is consumed by ET. Quantification of ET is used for many purposes, including crop production, water resources management, and environmental assessment. In agriculture, accurate quantification of ET is important for effective and efficient irrigation management (Irmak, 2009). The ET data for agricultural crops has become increasingly important in irrigation as well as in water resources management. It is dependent not only on the meteorological elements, but also on factors related to the crop, soil environment and management (Abu-Zeid and Hamdy, 2002).

Agricultural water users must plan an annual water budget in semi arid and arid lands and areas where water usage is regulated due to ecological protection programs, limited resources and competitive demand (Barrett, 1999). It is reasonable to expect that an improved crop water requirement estimate may make a substantial change in system size specifications and profitability. Sustainability of irrigated agriculture both environmentally and economically depends primarily on the efficiency of irrigation water, including crop water requirement and delivery and on-farm systems, management of degraded soils and water re-use (Howell, 2001). Therefore, a better management of water in irrigated agriculture is necessary to enhance crop production while preserving soil and water quality.

The semi arid areas in Ethiopia cover 301,500 square kilometers $\left(\mathrm{km}^{2}\right)$, which is $27 \%$ of the country and represent the crop production zone suffering from a serious moisture stress (Engida, 2000). It is in these areas that food insecurity and famine has always been reported (IGAD and FAO, 1995). Shortage of rainfall is normally reported as the cause of famine in Ethiopia. However, supplementary irrigation such as small irrigation and water harvesting methods have been undertaken to cope with the water stress problem during the crop growing period (maize and sorghum) in Adama and Miesso Districts (Degefie et al., 2004 ). Most of these adaptive measures are undertaken at farm level.

Unreliable and poor distribution of rainfall is one of the major causes for low yield of sorghum in Ethiopia and it is a staple food crop for millions of people who live in the dry land areas of the country. So, farmers and private sales are now opting for the production of this crop under supplemental and/or full irrigation. Under such situation, crop specific water requirement is a key parameter in providing growers with information to select varieties for production and to determine the timing and quantity of irrigation events. Availability of experimentally
Sci. Technol. Arts Res. J., July-Sep 2013, 2(3): 16-24

determined crop coefficient and crop water requirement is important for proper irrigation scheduling, efficient water management, optimum yield and profit. However, there is a lack of locally determined crop coefficient for sorghum varieties used by the producers and hence difficult to determine the water requirement of the crops. Therefore, this study was conducted to determine the crop water requirement and develop crop coefficient for a sorghum variety at different growth stages.

\section{MATERIALS AND METHODS}

\section{Description of the Experimental Site}

The experiment was conducted at the Melkassa Agricultural Research Center (MARC), Central Rift Valley of Ethiopia, which is $15 \mathrm{~km}$ southeast of Nazareth town located at $8^{\circ} 24^{\prime} \mathrm{N}$ and $39^{\circ} 21^{\prime} \mathrm{E}$ with an altitude of 1550 meter above sea level (MoA, 2000). The main rainy season for this site is during the summer from June to September (Kiremt) which contributes about $69 \%$ of its annual rainfall and the second short rainy season $(B e l g)$ is from March to May which covers nearly $24 \%$. The third season, which is from October to January (Bega), is dry most of the time but contributes around $7 \%$ of the annual rainfall especially during October and January for the late cessation of Kiremt and early onset of Belg seasons, respectively. For the period 1977-2006, the annual average rainfall is $702 \mathrm{~mm}$ and it ranges from 450 to $918 \mathrm{~mm}$. The peak months are July and August with an average rainfall of 157.5 and $161.6 \mathrm{~mm}$, respectively. The long-term mean rainfall for the Bega, Belg and Kiremt seasons is 52,166 and $482.5 \mathrm{~mm}$, respectively. For the period 1977-2006, the daily mean maximum and minimum temperatures are 28.5 and $13.8^{\circ} \mathrm{C}$, respectively. The mean maximum temperature is between $30.9{ }^{\circ} \mathrm{C}$ during May and $26.2{ }^{\circ} \mathrm{C}$ during August (Gebru and Abebe, 2011). According to the recent agro-ecological zones classification of Ethiopia (MoA, 2000), the Melkassa Hypo Calcic Regosol ecotope falls in the zone termed hot to warm semi arid lowlands. Loam and clay loam soil textures are the dominant textural classes (MARC, 1995; Tsion et al., 2009).

\section{Experimental Setup}

One drainage type lysimeter located $100 \mathrm{~m}$ away from the Meteorological Station of the Melkassa Agricultural Research Center was used for the study. The lysimeter used was rectangular in shape with $2 \mathrm{~m}^{2}$ area and effective soil depth of $100 \mathrm{~cm}$ and additional $100 \mathrm{~cm}$ layers, $20 \mathrm{~cm}$ rock, $20 \mathrm{~cm}$ gravel and $20 \mathrm{~cm}$ sand pack underneath which collects excess water from the upper soil and discharge it to the drainage collector placed in the working chamber through a drainage pipe. The 
Abebe Shenkut et al.,

lysimeter has champers for aeration and drainage pipes connected to water collecting tank which is placed in the working area underneath the lysimeter. The heights of the lysimeter rims are maintained near the ground level to minimize the boundary layer effect in and around the lysimeter. However, the rims of lysimeter were protruded 20 $\mathrm{cm}$ above the soil surface so that no surface runoff water enters into the lysimeter.

\section{Soil Sampling and Analysis}

Approximately 200 grams of soil sample was taken from inside the lysimeter at an interval of 15 $\mathrm{cm}$ up to $105 \mathrm{~cm}$ depth for determination of soil physical properties like soil texture, bulk density (BD), field capacity (FC) and permanent wilting point (PWP). Particle size distribution was determined using the Bouyoucos hydrometer method. Bulk density was determined by taking undisturbed soil sample from the site using core sampler method. The water content at FC and PWP were determined by the pressure plate apparatus technique whereas total available water (TAW) was obtained by subtracting PWP from FC (Ryan et al., 2001).

$$
\mathrm{TAW}=\left(\frac{\mathrm{FC}-\mathrm{PWP}}{100}\right) \times \mathrm{BD} \times \mathrm{d}
$$

where TAW $=$ Total available water $(\mathrm{cm}), \mathrm{FC}=$ Field capacity $(\%)$, PWP $=$ Permanent wilting point $(\%)$, $\mathrm{BD}=$ Bulk density $\left(\mathrm{g} \mathrm{cm}^{-3}\right)$ and $\mathrm{d}=$ Depth of root zone $(\mathrm{cm})$.

The physical properties of the experimental soil (texture, bulk density, field capacity, permanent wilting point and total available water) are determined. The soil textural class was clay loam within the soil profile considered. The values of FC, PWP and TAW were $31.26 \%, 16.35 \%$ and $14.90 \%$, respectively, while the average bulk density was $1.13 \mathrm{~g} \mathrm{~cm}^{-3}$ per meter.

\section{Neutron Probe Calibration}

The neutron probe was calibrated based on the procedure given in the user manual (Model 503DR CPN Hydro probe). The instrument allows rapid and periodically repeated measurements of volumetric wetness of a soil at different depths. During the calibration of the neutron probe, access tubes, volume sample, a scale and oven were used. Two aluminum access tubes were installed at depth of $105 \mathrm{~cm}$ at two points. This was done by digging a hole with an auger, and the aluminum access tube was driven into the hole. Wet and dry points were established to obtain wide range of moisture and to make it possible for the probe to read these ranges.

Probe readings in the tube in count ratio or rat (count/standard count) unit and volume sampler in pairs around the tube (within $15 \mathrm{~cm}$ of the tube)

\section{Sci. Technol. Arts Res. J., July-Sep 2013, 2(3): 16-24}

were taken at the desired depth. Parallel to the neutron probe measurements, soil samples were taken at $15 \mathrm{~cm}$ interval up to $105 \mathrm{~cm}$ soil depth with the same depth of neutron probe readings using an auger and soil water at $15 \mathrm{~cm}$ soil depth was calculated using the gravimeter method (user manual). The probe reading in count ratio (rat) versus the volume samples data was plotted and entered into an Excel spread sheet, a trend line created with its slope and, displayed its $R^{2}$ value. The coefficients of the linear equation ( $a$ and $b$ ) obtained from the fitted curves were used to convert neutron probe readings to soil moisture readings in unit of $15 \mathrm{~cm}$ depth of water per $15 \mathrm{~cm}$ of soil depth.

\section{Input Data Collection for Water Balance}

\section{Soil Moisture Measurement}

After calibrating the neutron probe, soil moisture content was monitored daily using the neutron probe sensor at an interval of $15 \mathrm{~cm}$ to a depth of $105 \mathrm{~cm}$ through one access tube installed within the lysimeter whereas the top $15 \mathrm{~cm}$ soil depth was measured gravimetrically.

\section{Irrigation Application}

Irrigation water was applied to the crop when $55 \%$ depletion of the available soil moisture occurred within the crop root zone (Doorenbos and Kassam, 1979; Allen et al., 1998). This 55\% depletion was considered for the effective root zone of the crop (one meter). Similar irrigation amount at this depletion was given to the crop inside and outside the lysimeter to ensure uniform plant growth. The application of irrigation was carried out with known volume of buckets by converting the $55 \%$ depletion into volume of water. The amount of applied irrigation water was calculated using the following formula (Brouwer et al., 1985):

$$
\mathrm{V}=\mathrm{A} \times \mathrm{D}
$$

where $V=$ Amount of water to be added $\left(\mathrm{m}^{3}\right), \mathrm{A}=$ Surface area of lysimeter $\left(\mathrm{m}^{2}\right)$, and $D=$ Depth of application (m).

\section{Climatic Parameters and Drainage}

Rainfall, sunshine hours, air temperature, relative humidity and wind speed values were collected daily from the Meteorological Station located $100 \mathrm{~m}$ away from the lysimeter. Drainage was collected from water tanks that collect water underneath the lysimeter using graduated buckets.

\section{Crop Planting and Protection}

Before sowing, the lysimeter was moistened by pre-irrigation to facilitate early growth and normal root growth. Eighteen plants of Gambella-1107 sorghum variety were sown on 28/05/2011 inside the lysimeter. The same variety was sown around 
Abebe Shenkut et al.,

the lysimeter in order to maintain a similar environment. The total plot size of lysimeter inside and outside was $5 \times 6 \mathrm{~m}$ with a net area of $2 \times 1 \mathrm{~m}$. The row and inter row spacing used were 75 and 15 $\mathrm{cm}$, respectively. Recommended doses of $50 \mathrm{~kg} / \mathrm{ha}$ Urea $(46 \% \mathrm{~N})$ and $100 \mathrm{~kg} / \mathrm{ha}$ DAP $\left(46 \% \mathrm{P}_{2} \mathrm{O}_{5}\right.$ and $18 \% \mathrm{~N}$ ) were applied to the crop at knee height stage and the time of sowing using row band placement by hand, respectively. Plants were protected from sorghum 'shoot fly' by applying the chemical insecticides of 'Endosulfan', by keeping fields cleared and frequently monitored. The crop was harvested on 09/10/2011.

\section{Agronomic and Yield Data Collection}

Plant height, leaf area and root length were collected. Among the growth parameters plant height and leaf area were measured at each growth stage from five random plants from the plot. Leaf area was determined using the methods described by Sticker et al. (1961) and Mass et al. (1987) as follows:

$\mathrm{LA}=\mathrm{W} \times \mathrm{L} \times 0.75$

where LA $=$ Leaf area $\left(\mathrm{cm}^{2}\right), \mathrm{W}=$ Maximum leaf width $(\mathrm{cm}), L=$ Leaf length $(\mathrm{cm})$ and $0.75=$ Correction factor for sorghum. Leaf area index (LAl) was calculated as the ratio of leaf area of the five sampled plants to the area of land occupied by these plants (Diwaker and Oswalt, 1992).

In order to monitor the effective root zone at different growth stages, root length was observed during each growth stages and measured at the end of the crop growing season by uprooting sample plants. The root reached to $105 \mathrm{~cm}$ soil depth during the growing season. The grain yield per plot was measured after harvesting the net plot area and then the grain yield was adjusted to $12.5 \%$ moisture content by electronic moisture tester and converted it to on hectare basis. In addition to this, 1000 seeds from the plot was counted by electrical seed counter and weighed with electrical sensitive balance.

\section{Determination of Crop Evapotranspiration and Reference Evapotranspiration}

The $\mathrm{ET}_{\mathrm{c}}$ at any given time was calculated using the water balance or water budget equation (Khan et al., 1993; Allen et al., 1998) as:

$$
\mathrm{ET}_{\mathrm{c}}=\mathrm{I}+\mathrm{RF}-\mathrm{D} \pm \Delta \mathrm{S}
$$

where $\mathrm{ET}_{\mathrm{C}}=$ Crop evapotranspiration, I = Irrigation applied $(\mathrm{mm}), \mathrm{RF}=$ Rainfall received in the season $(\mathrm{mm}), \mathrm{D}=$ Drainage $(\mathrm{mm})$ and $\Delta S=$ Change in soil water $(\mathrm{mm})$.

The reference evapotranspiration of the site under consideration for each growth stage of the crop was estimated using CROPWAT 4 windows version 4.2. This program uses sunshine hours, air
Sci. Technol. Arts Res. J., July-Sep 2013, 2(3): 16-24

temperature (maximum and minimum), relative humidity and wind speed at 2 meter height to calculate $\mathrm{ET}_{0}$ using the Penman-Monteith equation (Allen et al., 1998).

\section{Determination of the Crop Coefficient}

The growing period was divided into four distinct growth stages: initial, development, mid-season and late-season. The $\mathrm{K}_{\mathrm{c}}$ values at each crop stages were calculated using the following equation (Allen et al., 1998):

$$
\mathrm{K}_{\mathrm{c}}=\frac{\mathrm{ET}_{\mathrm{c}}}{\mathrm{ET}_{\mathrm{o}}}
$$

where $\mathrm{K}_{\mathrm{c}}=$ Crop coefficient, $\mathrm{ET}_{\mathrm{c}}=$ Crop evapotranspiration $\left(\mathrm{mm} \mathrm{day}^{-1}\right)$ and $\mathrm{ET}_{\mathrm{O}}=$ Reference crop evapotranspiration $\left(\mathrm{mm} \mathrm{day}^{-1}\right)$. The crop and reference evapotranspiration, crop coefficient and other crop parameters collected were analyzed using descriptive statistics and mean values are presented for most of the parameters.

\section{RESULTS AND DISCUSSIONS}

\section{Yields}

The yield obtained was 5.3 tones $(t)$ ha $^{-1}$. This yield level for Gambella-1107 is higher than the reported yield of the same variety $\left(2.5-3 \mathrm{t} \mathrm{ha}^{-1}\right)$ grown in semi arid areas including Gambella, Yabello, Jijga, Kobo and Shewa Robit (Kidane et al., 2010). A good yield under irrigation for sorghum is reported to be 3.5 to $5 \mathrm{t} \mathrm{ha}^{-1}$ using 12 to $15 \%$ moisture content (Doorenbos and Kassam, 1979). Gambella-1107 sorghum variety grain yields obtained from onresearch field $\left(3-5 \mathrm{tha}^{-1}\right)$ is substantially higher than that of on-farm field $\left(2-3 \mathrm{t} \mathrm{ha}^{-1}\right)$ (EARO, 2004). The variation of yield obtained in this study with that of the reported yield performance is due to location and good water management during the whole growth stage of the crop.

\section{Crop Growth Parameters}

The observed length of crop growth stages during the trial were found to be $20,30,40$ and 30 days for initial, crop development, mid-season and late-season stages, respectively, with a total growing period of 120 days. The growth of Gambella-1107 was assessed as the seasonal change of plant height, leaf area (LA) and leaf area index (LAl).

The LAl was lowest at initial stage due to small leaf area (Table 1). The LA and LAl as well as plant height increased consistently from initial to the development \& mid-season stages. The maximum LAI was achieved when the plants reach their maximum height at mid-season stage with high crop evapotranspiration due to leaf enlargement that increases transpiration. At this stage of plant 
Abebe Shenkut et al.,

development, LA and LAI started to decrease, whereas plant height remained relatively constant for the rest of the season. The decrease in LA and
Sci. Technol. Arts Res. J., July-Sep 2013, 2(3): 16-24

LAl was due to the maturity of the crop associated with leaf ageing, senescence and dropping of leaves.

Table 1: Growth stage wise leaf area, leaf area index, plant height and $\mathrm{ET}_{\mathrm{c}}$ of Gambella-1107 grown in a lysimeter at Melkassa.

\begin{tabular}{ccccc}
\hline Growth stage & $\mathbf{L A}\left(\mathbf{c m}^{2}\right)$ & LAl & $\mathbf{p H}(\mathbf{c m})$ & $\mathbf{E T}_{\mathbf{c}}$ \\
\hline Initial & 270.0 & 0.2 & 25.8 & 53.8 \\
Development & 4740.2 & 4.2 & 130.5 & 138.5 \\
Mid-season & 5564.9 & 4.9 & 189.0 & 214.4 \\
Late season & 1768.4 & 1.6 & 189.0 & 94.0 \\
\hline LA = Leaf area, LAl = Leaf area index, $\mathrm{pH}=$ Plant height and $\mathrm{ET}_{\mathrm{c}}=$ Crop evapotranspiration
\end{tabular}

\section{Crop Evapotranspiration}

The decadal and seasonal $\mathrm{ET}_{\mathrm{c}}$ of sorghum Gambella-1107 variety and the components of the water balance are presented in Table 2. The crop received a seasonal total of 76.2 and $610.8 \mathrm{~mm}$ of water in the form of irrigation and rainfall, respectively. However, $177.1 \mathrm{~mm}$ of water was lost from the soil in the form of drainage (Table 2).

Table 2: Decadal values of water balance components and crop evapotranspiration

\begin{tabular}{lllll}
\hline \multicolumn{5}{c}{ Ten days water balance components } \\
\hline DAP & $\mathbf{I}(\mathbf{m m})$ & $\mathbf{R F}(\mathbf{m m})$ & $\mathbf{D}(\mathbf{m m})$ & $\Delta \mathbf{S}(\mathbf{m m})$ \\
\hline 10 & 21.9 & 7.0 & 0.0 & -0.4 \\
20 & 23.6 & 33.5 & 10.0 & -21.9 \\
30 & 30.7 & 6.9 & 0.0 & 19.7 \\
40 & 0.0 & 73.2 & 24.5 & -8.8 \\
50 & 0.0 & 42.0 & 5.5 & 4.8 \\
60 & 0.0 & 62.4 & 0.0 & -0.5 \\
70 & 0.0 & 10.6 & 0.0 & 41.7 \\
80 & 0.0 & 109.3 & 0.0 & -61.3 \\
90 & 0.0 & 44.5 & 17.0 & 24.7 \\
100 & 0.0 & 108.0 & 35.1 & -41.4 \\
110 & 0.0 & 92.4 & 65.3 & 7.7 \\
120 & 0.0 & 21.0 & 19.8 & 26.4 \\
\hline Total & $\mathbf{7 6 . 2}$ & $\mathbf{6 1 0 . 8}$ & $\mathbf{1 7 7 . 1}$ & $\mathbf{- 9 . 2}$ \\
\hline
\end{tabular}

$\mathrm{DAP}=$ Days after planting, $\mathrm{I}=$ Irrigation, $\mathrm{RF}=$ Rainfall, $\mathrm{D}=$ Drainage and $\Delta \mathrm{S}=$ Change in soil moisture storage .

The decadal $\mathrm{ET}_{\mathrm{c}}$ values ranged from 25.2 to 61.9 $\mathrm{mm}$. Higher $E T_{c}$ values were recorded from 30-90 days after planting as compared to the values in the beginning and end of the crop life cycle. The fluctuation in $\mathrm{ET}_{\mathrm{c}}$ throughout the season is expected because of changes not only in the crop development but also daily changes in weather parameters such as radiation, humidity, wind speed and temperature. Crop evapotranspiration increases with increasing air temperature and solar radiation, the two primary drivers of ET (Irmak, 2009). The total water requirement of the studied sorghum variety was found to be $500.7 \mathrm{~mm}$ (Table 1). This total $\mathrm{ET}_{\mathrm{c}}$ of the variety considered in this study was within the range of previous reports such as 450 $650 \mathrm{~mm}$ (Doorenbos and Kassam, 1979) and 491 $533 \mathrm{~mm}$ (Piccinni et al., 2006) while exceeds the range $(210-293 \mathrm{~mm})$ reported by Sheng-Feng et al. (2006).
Computation of water requirement based on crop growth stage indicated differential water requirement of the crop throughout the course of crop development. The measured $\mathrm{ET}_{\mathrm{c}}$ values were 53.8, 138.5, 214.4 and $94.0 \mathrm{~mm}$ during the initial, development, mid-season and late season stages, respectively (Table 1). The highest water requirement was recorded at the mid-season stage followed by the development stage while the lowest was observed at the initial growth stage. The lowest crop water requirement at the initial stage is mainly due to the low crop leaf area development (Table 1) with a low transpiration capacity. On the other hand, the rapid reduction in $\mathrm{ET}_{\mathrm{c}}$ in the late season stage was due to the physiological deterioration of leaves because of aging. The period of maturity coincides with the period of less water demand because of drying of leaves and minimum leaf area available for transpiration (Kassam et al., 1975). 
Abebe Shenkut et al.,

\section{Reference Evapotranspiration}

The $\mathrm{ET}_{\mathrm{o}}$ attained its maximum during the initial crop growth stage which could be attributed to the high evaporative demand of the atmosphere (Figure
Sci. Technol. Arts Res. J., July-Sep 2013, 2(3): 16-24

1). There was a decrease in $E T_{0}$ from the initial to the end of the late season stage with fluctuating trend which was attributed to the variability of climatologically factors during the growing season.

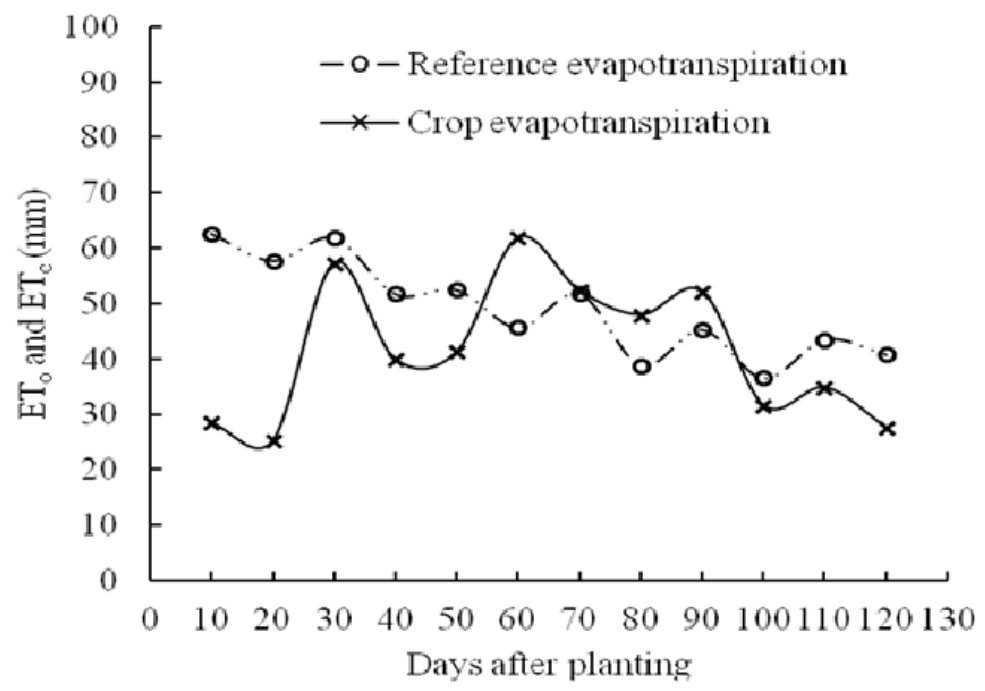

Figure 1: Decadal crop evapotranspiration $\left(E T_{c}\right)$ of Gambella-1107 and reference evapotranspiration ( $E T_{0}$ ) as a function of days after planting for the crop at Melkassa.

Moreover, the $\mathrm{ET}_{\mathrm{c}}$ exceeded $\mathrm{ET}_{\mathrm{o}}$ from 60 - 90 days after planting which coincided with the midseason stage of the crop demand for high water use due to flowering, grains formation and filling. The rapid decrease in $\mathrm{ET}_{\mathrm{c}}$ from the end of mid-season to late season stage (Figure 1) was due to leaf senescence and to the completion of grain formation and filling thereby limiting transpiration. The crop water use declined from the mid-season to the late season stage which is attributed to the cessation of leaf growth and a corresponding decrease in water demand (Allen et al., 1998).

\section{Crop Coefficient}

The curve presented in Figure 2 represents the changes in the $\mathrm{K}_{\mathrm{c}}$ over the length of the growing season. The shape of the curve represents the changes in the vegetation and ground cover during plant development and maturation that affect the ratio of $E T_{c}$ to $E T_{0}$. The decadal $K_{c}$ increased from the initial to development stages while reached its highest and relatively remained constant at the midseason stage (Figure 2). The $\mathrm{K}_{c}$ declined rapidly during the late season stage. Higher $\mathrm{K}_{\mathrm{c}}$ values were recorded from 60-90 days after planting as compared to the values in the beginning and end of the crop life cycle. The maximum $\mathrm{K}_{\mathrm{c}}$ value was 1.35 at 60 days after planting for the reason that low evaporative demand of the atmosphere $\left(E T_{0}\right)$ and rainfall that increases $\mathrm{ET}_{\mathrm{c}}$.

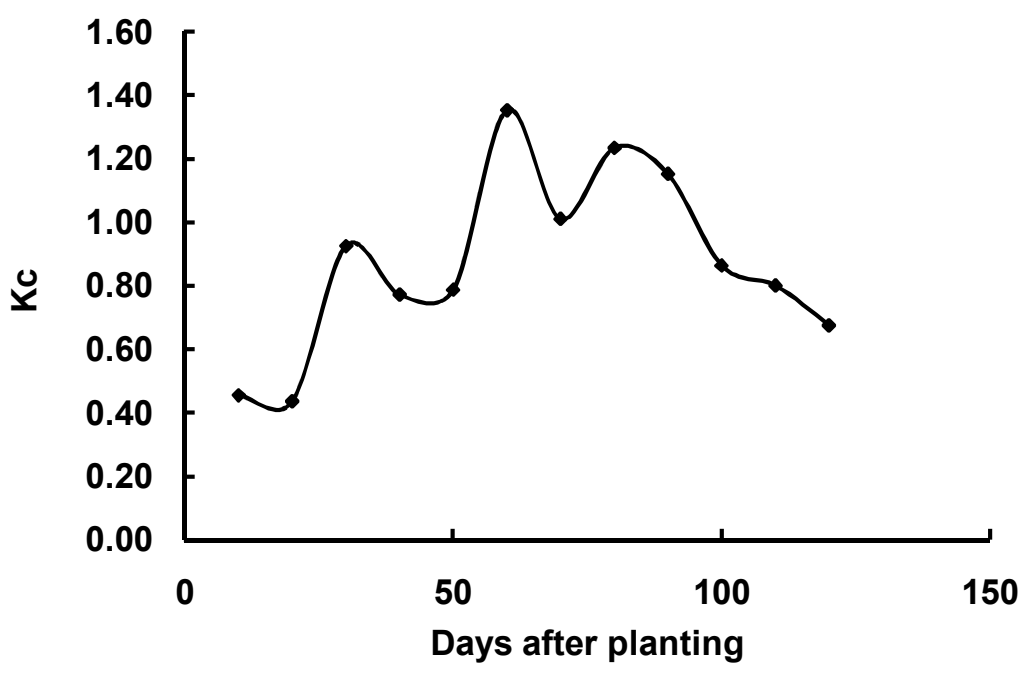

Figure 2: Decadal course of crop coefficients $\left(\mathrm{K}_{\mathrm{c}}\right)$ for Gambella-1107 grown in a lysimeter at Melkassa. 


\section{Abebe Shenkut et al.,}

It can be observed that there was high variation in $\mathrm{K}_{\mathrm{c}}$ values among stages (Table 3 ). This is because the $K_{c}$ values change very rapidly with the
Sci. Technol. Arts Res. J., July-Sep 2013, 2(3): 16-24

changes in crop development (Table 3 ). The $\mathrm{K}_{\mathrm{c}}$ value ranged from 0.45 at the initial growth stage to 1.18 at the mid-season stage.

Table 3: Stage wise crop coefficient $\left(\mathrm{K}_{\mathrm{c}}\right)$ values during the growing season.

\begin{tabular}{ccccc}
\hline & Initial & Development & Mid-season & Late season \\
\hline $\mathbf{K}_{\mathrm{c}}$ & 0.45 & 0.83 & 1.18 & 0.78 \\
FAO $\mathbf{K}_{\mathrm{c}}$ & 0.40 & $0.70-0.75$ & $1.0-1.15$ & $0.75-0.80$ \\
\hline \multicolumn{3}{c}{$\mathrm{K}_{\mathrm{c}}=$ Crop Coefficient and FAO = Food and Agricultural Organization. }
\end{tabular}

The $\mathrm{K}_{\mathrm{c}}$ values initially were higher (Table 3 ) due to a high evaporation from the wetted topsoil in a semi arid environment. The arid and semi arid zones have long hours of bright sunshine which leads to high radiation incidence leading to higher ET rate (Indinoba et al., 2008). During the initial period, the leaf area is small, and ET is predominately in the form of soil evaporation. Consequently, the advancement of $\mathrm{K}_{\mathrm{c}}$ values reflected the effects of crop growth, development and physiology on $\mathrm{ET}_{c}$ (Allen et al., 1998). The increase in $\mathrm{K}_{\mathrm{c}}$ values from the initial stage up to the mid-season stage was due to increases in leaf area and plant height (Table 1). The $\mathrm{K}_{\mathrm{c}}$ values increased radically as the crop developed and covered the ground very effectively. Hence, the amount of water extraction increased with plant growth which in turn increased the $E T_{c}$. the rate of which is at the maximum level when the plant is fully developed (Irmak, 2009).

The $\mathrm{K}_{\mathrm{c}}$ values declined from the mid-season stage to the late season stage (Figure 3 ). This was accounted for the leaf aging and senescence. Senescence is usually associated with less efficient stomatal conductance (Miderios et al., 2001) and decreased leaf surface (Villabos et al., 2004) due to the effects of aging which restricts transpiration causing a reduction in $\mathrm{K}_{\mathrm{c}}$ (Allen et al., 1998).

The sorghum $K_{c}$ values obtained in this experiment were higher in the first three consecutive crop growth stages from the range of those recommended by FAO while at the late season stage it was within the range of the values reported in FAO publications (Table 3). For sorghum, Allen et al. (1998) reported $\mathrm{K}_{\mathrm{c}}$ values between $1.0-1.10$ at the mid-season and 0.55 at the late season stages. Bashir et al. (2006) the estimated $\mathrm{K}_{\mathrm{c}}$ values at the initial, the development, the mid-season and the late season stages were $0.62,0.85,1.15$ and 0.48 , respectively. Piccinni et al. (2006) who worked on sorghum in lysimeter obtained $\mathrm{K}_{\mathrm{c}}$ values of 0.40 at the initial, 0.80 at the mid-season and 0.75 at the late season stages. Sheng-Feng et al. (2006) reported $\mathrm{K}_{\mathrm{c}}$ values of $0.44,0.71,0.87$ and 0.62 at the initial, development, mid-season and late season stages, respectively, for sorghum variety grown in lysimeter. The variation of $\mathrm{K}_{\mathrm{c}}$ values in this study with that of FAO and others could be due to the growing season, climate, crop variety, and soil differences. In support of this, Simon et al. (1998) reported seasonal differences in $\mathrm{K}_{\mathrm{c}}$ of maize in Trinidad showing higher $K_{c}$ values (1.13 to 1.41) in the wet season and lower values (0.73 to 0.94$)$ in the dry season.

\section{CONCLUSIONS}

In finally, the $E T_{c}$ and $K_{c}$ of Gambella-1107 variety was evaluated at each growth stages for Melkassa and areas which have similar climate and soil characters. The values of $\mathrm{ET}_{\mathrm{c}}$ and $\mathrm{K}_{\mathrm{c}}$ obtained at Melkassa can be used for further studies related to water management like deficit irrigation and erratic rainfall for those areas with similar climate and soil conditions. Since $E T_{c}$ and $K_{c}$ are a function of crop characteristics, irrigation water management, climate conditions, local and agricultural practices, it should be localized and this result can be used for appropriate irrigation planning, to have accurate irrigation schedule, for deficit irrigation and hydrologic water studies.

According to the study, it was shown that estimates of crop water requirement made with locally determined crop coefficients differ from estimates of FAO publications and others. This emphasizes the strong need for local calibration of $\mathrm{K}_{\mathrm{c}}$ for each crop variety. The results of $E T_{\mathrm{c}}$ and $\mathrm{K}_{\mathrm{c}}$ show to be somewhat dependent on, crop variety, climate, location and growing season. The studied variety, $\mathrm{K}_{\mathrm{c}}$ values obtained at Melkassa can be beneficial to areas with similar soil type, climate, and location as that of Melkassa.

\section{ACKNOWLEDGMENTS}

The author would like to express his appreciation and deepest gratitude to his Major Advisor, Dr. Kindie Tesfaye, and Co-advisor, Dr. Fentaw Abegaz, for all their sincere, faithful, immense devotion, supervision, constructive comments, endless support. He would also like to thank Dr. Tilahun Hordofa, his instructor, for his sincere, 
Abebe Shenkut et al.,

faithful, immense devotion, support, helpful guidance, supervision and encouragement. The author would also like to express his deepest gratitude to Ministry of Education for financing all his study and research costs. The author is deeply grateful to the University of Choice, Haramaya University, Ethiopia, for accessing all the school materials like Internet and computer pool. His special thanks are extended to staff of Melkassa Agricultural Research Center specially soil and water conservation case team colleagues for providing him material support and experienced guidance for the success of this study. The author also happy to express his special gratitude to $\mathrm{Mr}$. Dereje Ayalneh and Mohamed, who helped him in Laboratory analysis on the physical properties of soil samples. The author is pleased to thank all the meteorological office workers for sharing all the meteorological data.

\section{REFERENCES}

Abu-Zeid, M., Hamdy, A. (2002). A report on World Water Council $3^{\text {rd }}$ World Water Forum, Cairo, Egypt. Water vision for the twenty-first century in the Arab World. Draft document.

Allen, R.G., Walter, I.A., Elliott, R.L., Howell, T.A., Itenfisu, D., Jensen, M.E., Snyder, R.L. (2005). The ASCE Standardized Reference Evapotranspiration Equation. Reston, Virginia. Pp.192.

Allen, R.G., Pereira, L.S., Raes, D., Smith, M. (1998). A report on Crop evapotranspiration. Guidelines for computing crop water requirements, FAO, Rome, Italy. Draft document

Allen, R.G., Smith, M., Perrier, A., Pereira, L.S. (1994). An update for the definition of reference evapotran spiration. Journal of International Commission on Irrigation and Drainage Bulletin 43: 1-34.

Barrett, M.E. (1999). A report on Texas Natural Resource Conservation Commission. Complying with the Edwards Aquifer rules: Technical Guidance on Best Management Practices/Prepared for the Texas Natural Resources Conservation Commission by the Center for Research in Water Resources, Bureau of Engineering Research, University of Texas, Austin. Draft document.

Bashir, M.A., Hata, T., Abdelhadi, A.W., Tanakamaru, H., Tada, A. (2006). Satellite-based evapotranspiration and crop coefficient for irrigated sorghum in the Gezira scheme, Sudan. Journal of Hydrology and Earth System Sciences 3: 793 -817.

Brouwer, C., Goffeau, A., Heibloem, M. (1985). Irrigation Water Management: Training Manual No.1. FAO (Food and Agriculture Organization) of the United Nations, Rome, Italy. Draft document.

Brouwer, C., Heibloem, M. (1986). A report on irrigation water needs. Irrigation water management: Training Manual, FAO (Food and Agriculture Organization), Rome, Italy. Draft document.
Sci. Technol. Arts Res. J., July-Sep 2013, 2(3): 16-24

Degefie Tibebe., Abebe Tadege., Kidane Giorgis (2004). Estimating crop water use and simulating yield reduction for maize and sorghum in Adama and Miesso districts using the CROPWAT Model. Ethiopian Institute of Agricultural Research, Addis Ababa, Ethiopia. Available at. http://www.ceepa.co.za /docs/CDPNo31.pdf. Accessed November 19, 2011.

Diwaker, B., Oswalt, D.L. (1992). Research Planning and Data Handling. ICRISAT (International Crops Research Institute for the Semi-Arid Tropics). Andhra Pradesh, India. Pp.89.

Doorenbos, J., Kassam, A.H. (1979). FAO (Food and Agriculture Organization) irrigation and drainage No. 33.Yield response to water, Rome, Italy. Draft document

Doorenbos, J., Pruitt, W.O. (1977). FAO (Food and Agriculture Organization) irrigation and drainage No. 24.Guidelines for predicting crop water requirements, Rome, Italy. Draft document.

Engida Mersha. (2000) A Desertification Convention Based on Moisture zones of Ethiopia. Ethiopian Journal of Natural Resources 1-9.

EARO (Ethiopian Agricultural Research Organization) (2004). Directory of released crop varieties and their recommended culutural practices. Addis Ababa, Ethiopia. Available at. http://www.eap.gov.et/sites/ default/files/released\%20crop\%20varities.pdf. Accessed February 08, 2012.

Gebru Jember, Abebe Tadege (2011). Natural Resources Management and Environment. Proceedings from National Workshop on Strengthening Capacity for Climate Change Adaptation in the Agriculture Sector in Ethiopia. Climate change, variability, trends and potential impacts and risks in major agro-ecological zones in Oromiya region, Ethiopia. Nazreth, Ethiopia. Draft document.

Howell, T.A. (2001). Enhancing water use efficiency in irrigated agriculture. Journal of Agronomy 93:281-289.

Indinoba, M.E., Idinoba, P.A., Gbadegesin, A., Jagtap, S.S. (2008). Growth and evapotranspiration of groundnut (Arachis hypogaea) in a transitional humid zone of Nigeria. African Journal of Agricultural Research 3: 384-388.

IGAD (Intergovernmental Authority for Development), FAO (Food and Agricultural Organisation) (1995). Agro-meteorology Working Paper Series No. 10. Crop Production System Zones of the IGAD sub-region. FAO, Rome, Italy. Draft document.

Irmak, S. (2009). Estimating Crop Evapotranspiration from Reference Evapotranspiration and Crop coefficients. University of Nebraska-Lincol web. http://extension. unl.edu/publications. Accessed 19 July 2011.

Jensen, M.E. (1968). Water Consumption by Agricultural Plants. In: Kozlowski TT (ed) Water Deficits and Plant Growth: II. Academic Press, Inc., New York, NY, pp 122.

Kashyap, P.S., Panda, R.K. (2001). Evaluation of evapotranspiration estimation methods and development of crop coefficients for potato crop in a 
Abebe Shenkut et al.,

sub-humid region. Journal of Agricultural Water Management 26: 67-80.

Kassam, A.A., Kowal, J.M., Harkness, C. (1975). Water use and growth of groundnut at Samaru, Northern Nigeria. Journal of Tropical Agriculture 52: 105-112.

Khan, B.R., Mainuddin, M., Molla, M.N. (1993). Design, construction and Testing of a lysimeter for a study of evapotranspiration of different crops. Journal of Agricultural Water Management 23: 183-197.

Kidane Giorgis., Alemneh Dejene., Meshack Malo (2010). Agricultural based Livelihood Systems in Drylands in the Context of Climate Change. Inventory of Adaptation Practices and Technologies of Ethiopia. Ethiopian Institute of Agricultural Research, Addis Ababa, Ethiopia. Available at.www.eap.gov.et/sites/ default/files/climatechangenlivelihood_kidane.pdf. Accessed February 08, 2012.

Liu, C., Xiying, Z., Maozheng, Y. (1998). Determination of daily evaporation and evapotranspiration of winter wheat field by large-scale weighing lysimeter and micro lysimeter. Journal of Hydraulic Engineering 7: 2001 -2008.

Mass, S.J., Arkin, G.F., Rosenthal, W.D. (1987). Relationship between the areas of successive leaves of graining sorghum. Journal of Agronomy 79: 739745.

MARC (Melkassa Agricultural Research Center) (1995) Experiences in lowland crops research. In: Habtu Assefa (ed) Proceedings of the $25^{\text {th }}$ Anniversary of Nazareth Research Center, 20-23 September 1995, Nazareth, Ethiopia, pp 24-29.

Miderios G.A., Arruda, F.B., Sakai, E., Fujiwara, M. (2001). The influence of crop canopy on evapotranspiration and crop coefficient of beans (phaseolus vulgaris L.). Journal of Agricultural Water Management 49: 211-224.

MoA (Ministry of Agriculture) (2000). Agro-Ecological Zones of Ethiopia, Natural Resource Management and Regulatory Department, Addis Ababa, Ethiopia. Draft document.

Monteith, J.L. (1965). Evaporation and environment. The State and Movement of Water in Living Organisms, $19^{\text {th }}$ Symposium, Society for Experimental Biology. Draft document.

Piccinni, G., Ko, J., Marek, T., Howell, T. (2006). Determination of growth-stage-specific crop coefficients $\left(\mathrm{K}_{\mathrm{c}}\right)$ of maize and sorghum: Chesterfield,
Sci. Technol. Arts Res. J., July-Sep 2013, 2(3): 16-24

USA. Journal of Agricultural Water Management 96: 1698-1704.

Ryan, J., Estefan, G., Rashid, A. (2001). Soil and Plant Analysis Laboratory Manual $\left(2^{\text {nd }}\right.$ ed). International Center for Agricultural Research in the Dry Areas (ICARDA) and the National Agricultural Research Center (NARC), Aleppo, Syria. pp172.

Sanchez, J.M., Lopez-Urrea, R., Rubio, E., Caselles, V. (2011) Determining irrigation needs of sorghum from two-source energy balance and radiometric temperatures: Barrax, Central Spain. Journal of Hydrology and Earth System Sciences 8: 3937-3960.

Sheng-Feng, K., Shin-Shen, H., Chen-Wuing, L. (2006). Estimation irrigation water requirements with derived crop coefficients for upland and paddy crops in ChiaNan Irrigation Association, Taiwan: ChiaNan Irrigation Projects, Taiwan. Journal of Agricultural Water Management 82: 433-451.

Simon, C.M., Ekwue, E.I., Gumbs, F.A., Narayan, C.V. (1998). Evapotranspiration and crop coefficients of irrigated maize (Zea mays L.) in Trinidad. Journal of Tropical Agriculture 75: 342-346.

Smith, D.I. (1998). Water in Australia: Resources and Management. Oxford University Press, South Melbourne.

Stanhill, G. (1973). Evaporation, transpiration and evapotranspiration: a case for ockham's razor. In: Hadas A (ed) Physical aspects of soil water and salts in ecosystems, Springer-Verlag, New York, pp 207220.

Sticker, F.C., Wearden, S., Pauli, A.W. (1961). Leaf area determination in grain sorghum. Journal of Agronomy 53: 187-188.

Tsion Tesfaye., Ranjan, S.K., Teklu Tesfaye (2009). Farmers training programme of Ethiopian Institute of Agricultural Research: An appraisal. African Journal of Agricultural Resource 4: 409-421.

Tyagi, N.K., Sharma, D.K., Luthra, S.K. (2000). Evapotranspiration and crop coefficients of wheat and sorghum. Journal of Irrigation and Drainage Engineering 4: 215-222.

Villabos, F.J., Testi, L., Rizzalli, R., Orgaz, F. (2004). Evapotranspiration and crop coefficients of irrigated garlic (Allium sativum L.) in a semi-arid climate. Journal of Agricultural Water Management 64: 233249. 